\title{
EFFECTIVENESS OF VACCINATION AGAINST INFLUENZA IN HIV-INFECTED PEDIATRIC PATIENTS IN THE 2016/2017 EPIDEMIC SEASON
}

\author{
SKUTECZNOŚĆ SZCZEPIENIA PRZECIWKO GRYPIE U PEDIATRYCZNYCH \\ PACJENTÓW ZAKAŻONYCH HIV W SEZONIE EPIDEMICZNYM 2016/2017
}

\author{
${ }^{1}$ Wroclaw Medical University, Department of Pediatric Infectious Diseases \\ Uniwersytet Medyczny im. Piastów Śląskich we Wrocławiu, Katedra i Klinika Pediatrii i Chorób Infekcyjnych \\ ${ }^{2}$ Wroclaw University of Environmental and Life Sciences, Department of Pathology, Division of Microbiology \\ Zakład Mikrobiologii Uniwersytetu Przyrodniczego we Wrocławiu
}

\begin{abstract}
BACKGROUND. Pediatric patients infected with the human immunodeficiency virus (HIV) are at risk of developing severe influenza. Vaccination against influenza in HIV $(+)$ children in Poland is recommended and free of charge. The aim of the study was to evaluate the effectiveness of influenza vaccination in this group of patients. MATERIAL AND METHODS. The study group consisted of $25 \mathrm{HIV}$-infected children, patients of the Department of Paediatric Infectious Diseases in Wrocław, vaccinated against influenza from September to December 2016. The incidence of influenza and influenza-like diseases was monitored from December 1, 2016 to April 15, 2017. IgG / IgM against influenza A and B by ELISA and against AH1N1 by HI method before vaccination and 4-6 weeks after vaccination were determined. Nasopharyngeal swabs of influenza RNA for PCR testing were collected in each patient during each hospitalization in the epidemic season.

RESULTS. In the 2016/2017 epidemic season, none of the patients developed symptomatic influenza or any other flu-like infection with fever. Influenza A virus RNA was detected in nasopharyngeal swabs in 8 patients, none of them presented any clinical symptoms of infection. Positive pre-vaccination IgG levels against influenza $\mathrm{A}$ and $\mathrm{B}$ were detected in $36 \%(9 / 25)$ and $68 \%(17 / 25)$ of patients, respectively. After vaccination, positive concentrations were found in 56\% (14/25) and 80\% (20/25) of patients, respectively. Positive concentration of IgM antibodies was achieved by $60 \%$ (15/25) of the respondents - for influenza A and 52\% (13/25) - for influenza B. In 11 patients $(45.8 \%)$ before vaccination, protective titres of antibodies against H1 haemagglutinin were obtained, after the vaccination the proportion of patients with a protective titer was $52.4 \%$.

CONCLUSIONS. Influenza vaccination in HIV-infected children is effective in preventing symptomatic influenza virus infection but does not prevent transmission of infection in the population. Annual influenza vaccination and seasonal natural infections with influenza viruses result in the persistence of measurable antibody levels until the next epidemic season.
\end{abstract}

Keywords: $H I V$, vaccination, influenza

\section{STRESZCZENIE}

WSTĘP. Pediatryczni pacjenci zakażeni ludzkim wirusem upośledzenia odporności (HIV) należą do grupy ryzyka ciężkiego przebiegu grypy. Szczepienia przeciw grypie dzieci HIV(+) w Polsce są zalecanie i bezpłatne. Celem badania była ocena skuteczności szczepienia przeciw grypie w tej grupie pacjentów.

MATERIAŁ I METODY. Badano 25 dzieci zakażonych HIV, pacjentów Kliniki Pediatrii i Chorób Infekcyjnych we Wrocławiu, zaszczepionych przeciw grypie od IX do XII 2016 r. Monitorowano zachorowalność na grypę i choroby grypopodobne od 01 XII 2016 do 15 IV 2017. Oznaczono IgG/IgM przeciwko wirusom grypy A i B metodą ELISA oraz przeciwko AH1N1 metodą ZH przed szczepieniem oraz 4-6 tygodni po szczepieniu. U każdego pacjenta, przy okazji każdej wizyty w klinice w sezonie epidemicznym pobierano wymazy na badanie PCR RNA. 
WYNIKI. W sezonie epidemicznym 2016/17 żaden z pacjentów nie zachorował na objawową na grypę ani inną infekcję grypopodobną z gorączką. W wymazach z nosogardła u 8 pacjentów wykryto RNA wirusa grypy A, żaden z nich nie prezentował objawów klinicznych infekcji. Dodatnie stężenia IgG przeciwko grypie A i B przed szczepieniem wykryto odpowiednio u 36\% (9/25) i 68\% (17/25) pacjentów. Po szczepieniu dodatnie stężenia wykazało odpowiednio u 56\% (14/25) i 80\% (20/25) pacjentów. Dodatnie stężenie przeciwciał w klasie IgM uzyskało $60 \%(15 / 25)$ badanych - dla grypy A i 52\% (13/25) - dla grypy B. U 11 pacjentów $(45,8 \%)$ przed szczepieniem wykazano ochronne miano przeciwciał przeciwko hemaglutyninie H1, po szczepieniu odsetek pacjentów z ochronnym mianem wynosił 52,4\%.

WNIOSKI. Szczepienia przeciw grypie u dzieci zakażonych HIV skutecznie zapobiegają objawowym zakażeniom wirusami grypy, ale nie zapobiegają transmisji zakażeń w populacji. Coroczne szczepienia przeciwko grypie i sezonowe zakażenia naturalne wirusami grypy skutkują utrzymywaniem się oznaczalnych stężeń przeciwciał do następnego sezonu epidemicznego.

Słowa kluczowe: HIV, szczepienia, grypa

\section{INTRODUCTION}

Each year millions of people suffer from seasonal influenza worldwide and there are also reported hundreds of thousands of deaths associated with this infection in the global scale(1). In the years 2016-2019, as much as 4-5 million cases of influenza were diagnosed or suspected in Poland (2). Patients with chronic chronic diseases (cardiovascular and pulmonary disease, diabetes, etc) and with immune deficiency (including acquired immune deficiency syndrome - AIDS) are at particular risk of severe, complicated influenza (1). Patients infected with human immunodeficiency virus (HIV), including children, are characterized by greater incidence of influenza, prolonged replication of the virus within the organism and eventually greater risk of hospitalization and mortality in the course of the disease $(3,4,5)$. The percentage of children suffering from influenza is $20-30 \%$ during the infection season annually $(6,7)$ and children aged $<5$ years have higher risk of hospitalization compared to older cohorts (8). A particularly high risk of developing influenza and its complications was found in certain African regions, where the percentage of HIV-infected children is the highest (9).

According to the Polish Immunization Programme, influenza vaccination with an inactivated intramuscular vaccine has been recommended for many years for HIV-infected paediatric patients from 6 months to 18 years (10). Vaccines for children are available free of charge, provided annually by the National AIDS Center (11). Experts emphasize that this is critically important to vaccinate not only infected patients but also people from their closest household contact $(12,13)$. Many studies have shown the acceptable effectiveness of influenza vaccine in HIV-infected children, but there is a lack of current data in Poland.

The aim of this analysis was to evaluate the clinical effectiveness of influenza vaccination in paediatric HIV-infected patients in the 2016/2017 epidemic

\section{WSTĘP}

Każdego roku na grypę sezonową zapada kilka milionów ludzi na świecie, odnotowuje się również kilkaset tysięcy zgonów w jej przebiegu (1). W latach 2016-2019 w Polsce stwierdzono od ponad 4 do 5 milionów zachorowań i podejrzeń zachorowań na grypę (2). Do grupy ryzyka ciężkiego przebiegu grypy i jej zagrażających życiu powikłań należą m.in. osoby z chorobami towarzyszącymi takimi jak: choroby układu sercowo-naczyniowego, choroby płuc, cukrzyca oraz zaburzenia odporności, m.in. zakażenie HIV (1). U pacjentów zakażonych HIV, w tym u zakażonych dzieci, wykazano wyższą zapadalność na grypę, dłuższe utrzymywanie się replikacji i wydalanie wirusa $z$ organizmu oraz wyższe ryzyko hospitalizacji i śmiertelność z powodu grypy w porównaniu do zdrowej populacji $(3,4,5)$. Podaje się, że w sezonie infekcyjnym odsetki dzieci chorujących na grypę oscylują w granicach $20-30 \%(6,7)$, ponadto u dzieci w wieku $<5$ roku życia istnieje wyższe ryzyko hospitalizacji w przebiegu grypy w porównaniu do starszych dzieci (8). Szczególnie wysokie ryzyko zachorowania na grypę i jej niepomyślnego przebiegu stwierdzono w regionach Afryki, gdzie odsetek dzieci zakażonych HIV jest najwyższy (9).

Zgodnie z polskim Programem Szczepień Ochronnych, już od wielu lat szczepienie przeciwko grypie przy użyciu domięśniowej szczepionki inaktywowanej jest zalecane dla pacjentów pediatrycznych zakażonych HIV w wieku od 6 miesięcy do 18 lat (10). Szczepionki dla dzieci dostępne są bezpłatnie, dostarczane corocznie przez Krajowe Centrum ds. AIDS (11). Jak podkreślają eksperci, konieczne jest nie tylko coroczne szczepienie zakażonych pacjentów, ale także osób z ich najbliższego domowego kontaktu $(12,13)$. W wielu badaniach wykazano zadowalającą skuteczność szczepionki przeciwko grypie wśród dzieci zakażonych HIV, brakuje jednak polskich aktualnych danych na ten temat. 
season, measured by: the incidence of influenza and influenza-like diseases, changes in the concentrations of specific antibodies against influenza $\mathrm{A}$ and $\mathrm{B}$, and the results of molecular tests (polymerase chain recation, PCR).

\section{MATERIAL AND METHODS}

We analyzed clinical records of $25 \mathrm{HIV}$-infected underage patients under the care of Department of Paediatric Infectious Diseases, University Hospital, Wroclaw, Poland (15 females), aged 1-18 years (median - 10 years). Twenty two of them were vaccinated against influenza more than once. Most of the patients were infected vertically, only one patient (16-year-old boy) was infected by sexual contact. The immune status of the patients at the time of vaccination was satisfactory (CD4 count within reference range). All patients were receiving combined antiretroviral therapy (cART) at the time of inclusion.

The last dose of inactivated trivalent influenza vaccine was administered to patients between September and December 2016. Three of 25 patients had not been vaccinated against influenza so far, therefore two of them, due to their age ( $<9$ years), received 2 doses of the vaccine in the 2016/2017 season. During the study, the incidence of influenza and influenza-like disease was monitored among patients from 1 December 2016 to 15 April 2017 by structured telephone interviews performed every month. Additionally, the concentrations of specific antibodies against influenza $\mathrm{A}$ and $\mathrm{B}$ viruses were measured using the Euroimmun Influenza $\operatorname{IgG}$ and IgM test (enzyme-linked immunosorbent assay, ELISA) and the hemagglutination inhibition test (HI) against the influenza A H1N1 virus was performed.

Antibody concentrations were determined in serum samples taken before the vaccination and 4-6 weeks thereafter. After the end of the epidemic season, the antibody concentration was also assessed in 17 patients. The antibody concentration $\geq 22$ relative units (RU) / $\mathrm{ml}$ was assumed as a positive result in the ELISA test according to the manufacturer's instructions. Further, titres $\geq 1: 40$ in the haemagglutination inhibition test (performed in the virology laboratory of the Wrocław University of Environmental and Life Sciences) were considered positive. For each patient included in the study we also collected nasopharyngeal swabs for routine testing for influenza RNA at each hospitalization during the epidemic season (regardless of the presence of clinical symptoms). The study was approved by the Bioethics Committee at Wroclaw Medical University.
Celem pracy była ocena skuteczności klinicznej szczepienia przeciwko grypie u pediatrycznych pacjentów zakażonych HIV w sezonie epidemicznym 2016/2017 mierzonej występowaniem zachorowań na grypę oraz choroby grypopodobne, wykonywaniem okresowych badań wirusologicznych (PCR) oraz zmianami stężeń specyficznych przeciwciał przeciwko wirusom gryp A i B.

\section{MATERIAŁ I METODY}

Badaniem objęto 25 pacjentów zakażonych HIV (15 dziewcząt, 60\%) w wieku 1-18 lat, mediana wie$\mathrm{ku}$ - 10 lat (22 szczepionych przeciwko grypie więcej niż jeden raz), pozostających pod stałą opieką Kliniki Pediatrii i Chorób Infekcyjnych we Wrocławiu. Większość stanowili pacjenci zakażeni wertykalnie, tylko jeden pacjent (16-letni chłopiec) zakaził się HIV drogą kontaktów seksualnych. Status immunologiczny pacjentów w momencie szczepienia był zadowalający (liczba CD4 w normie dla wieku). U wszystkich pacjentów stosowano skojarzoną terapię antyretrowirusową (combined antiretroviral therapy - cART).

Ostatnią dawkę inaktywowanej trójwalentnej szczepionki przeciwko grypie pacjenci otrzymali w okresie od września do grudnia 2016 r. Spośród 25 badanych, 3 pacjentów dotychczas nie było szczepionych przeciwko grypie, dlatego też dwoje z nich z uwagi na wiek (poniżej 9 r.ż.) otrzymało dwie dawki szczepionki w sezonie 2016/2017. W trakcie badania monitorowano zachorowalność na grypę i choroby grypopodobne wśród pacjentów od 1.12.2016 do 15.04.2017 poprzez zbieranie wywiadów telefonicznych przeprowadzanych jeden raz w miesiącu. Poza tym oceniano stężenia specyficznych przeciwciał przeciwko wirusom grypy A i B testem Euroimmun Influenza IgG i IgM metodą ELISA oraz testem hamowania hemaglutynacji (hemagglutination inhibition test - HI) w stosunku do wirusa grypy A H1N1. Stężenia i miana przeciwciał oznaczono w próbkach surowicy pobranych przed szczepieniem oraz $\mathrm{w}$ okresie 4-6 tygodni po szczepieniu. U 17 pacjentów oceniono również stężenie przeciwciał po zakończonym sezonie epidemicznym. Za wynik pozytywny w teście ELISA wg producenta przyjęto stężenie przeciwciał $\geq 22$ RU/ml (RU - relative units); a w teście zahamowania hemaglutynacji wykonanego w pracowni wirusologii Uniwersytetu Przyrodniczego we Wrocławiu, miana $\geq 1: 40$. U każdego włączonego do badania pacjenta, przy okazji każdej wizyty w klinice w sezonie epidemicznym (niezależnie od występowania objawów klinicznych) rutynowo pobierano wymazy z nosogardła na badanie RNA wirusów grypy metodą PCR. Wyniki opracowano przy wykorzystaniu programu STATISTICA 13.3 (TIBCO Software, Inc). 


\section{RESULTS}

In the 2016/2017 epidemic season, during the study period (01/12/2016 to $15 / 04 / 2017)$, none of the HIV-infected children vaccinated against influenza developed symptomatic influenza or any other flulike infection with fever. The RNA of influenza type A was found in 8 patients with routine nasopharyngeal swabs but none of these patients had any clinical signs of infection (Fig. 1). However, one of the caregivers (mother) accompanying the patient during the hospitalization had clinical symptoms of influenza and this aetiology was confirmed by a positive PCR test result. The boy was also found to have RNA of influenza virus on nasopharyngeal swab, but he had no clinical symptoms.

Before influenza vaccination, positive result for IgG antibodies against influenza $\mathrm{A}$ and $\mathrm{B}$ was detected in $36 \%(9 / 25)$ and $68 \%(17 / 25)$ of patients, respectively. With regard to $\operatorname{IgM}$ antibodies, positive test for influenza A and B was found in 24\% (6/25) and 20\% $(5 / 25)$ of patients, respectively.

Control tests performed no earlier than 4 weeks after the vaccination revealed positive IgG levels against influenza $\mathrm{A}$ in 56\% (14/25) of patients and in $80 \%(20 / 25)$ against influenza B (Fig. 2). Positive test for IgM antibodies was found in $60 \%(15 / 25)$ of the subjects for influenza A and 52\% (13/25) for influenza B. Detailed results are presented in the table (Tab. I).

IgG antibodies were measured in 17 patients after the influenza season, and they were found in $6(35.3 \%)$ and $3(17.6 \%)$ subjects against influenza $\mathrm{A}$ and $\mathrm{B}$, respectively. No positive antibody titre was found at this time. In 4 patients with confirmed RNA of influenza $\mathrm{A}$, IgG seroconversion was not found.

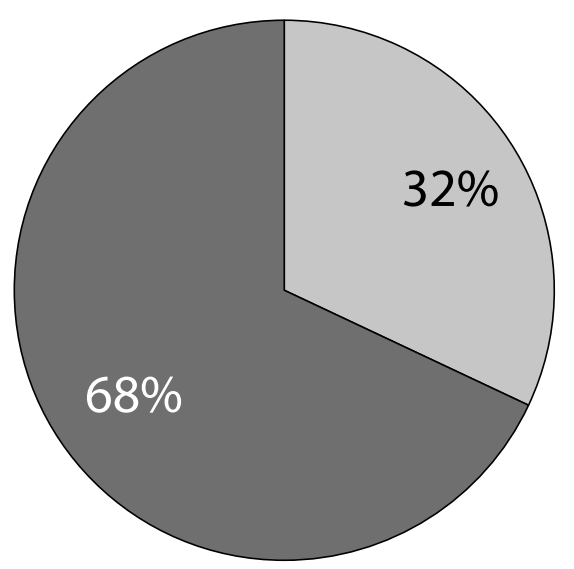

$\square$ dodatni $\square$ ujemny

Fig. 1. Results of RNA of influenza type A testing by PCR in the study group

Ryc. 1. Wyniki badania RNA wirusa grypy typu A metodą PCR w grupie badanej
Badanie uzyskało zgodę Komisji Bioetycznej Uniwersytetu Medycznego im. Piastów Śląskich we Wrocławiu.

\section{WYNIKI}

W sezonie epidemicznym 2016/2017, w okresie badania (od 01.12.2016 do 15.04.2017) żadne z zaszczepionych przeciwko grypie dzieci zakażonych HIV nie zachorowało na objawową grypę ani inną infekcję grypopodobną z gorączką. W rutynowo wykonywanych wymazach z nosogardła u 8 pacjentów wykazano RNA wirusa grypy A, żaden z pacjentów nie miał jakichkolwiek objawów klinicznych infekcji (Ryc. 1). Z kolei u jednego z opiekunów (matka) towarzyszącemu pacjentowi podczas wizyty w klinice stwierdzono kliniczne objawy grypy, których etiologię potwierdzono dodatnim wynikiem badania PCR. U chłopca - pacjenta - również wykazano obecność RNA wirusa grypy w wymazie z nosogardła, jednak nie prezentował on żadnych objawów klinicznych.

Przed szczepieniem przeciwko grypie dodatnie stężenie przeciwciał w klasie IgG przeciwko grypie A i B wykryto u odpowiednio 36\% (9/25) i 68\% (17/25) pacjentów. Z kolei dodatnie stężenie przeciwciał w klasie IgM przeciwko grypie A i B stwierdzono u $24 \%(6 / 25)$ pacjentów - dla grypy A i 20\% (5/25) pacjentów - dla grypy B.

Kontrolne oznaczenie po min. 4 tygodniach po szczepieniu wykazało dodatnie stężenia przeciwciał w klasie IgG u 56\% (14/25) i 80\% (20/25) pacjentów odpowiednio przeciwko grypie A i B (Ryc. 2). Dodatnie stężenie przeciwciał w klasie IgM uzyskało natomiast $60 \%(15 / 25)$ badanych - dla grypy A i 52\% (13/25) - dla grypy B. Szczegółowe wyniki w obu badanych klasach przeciwciał przedstawiono w tabeli (Tabela I).

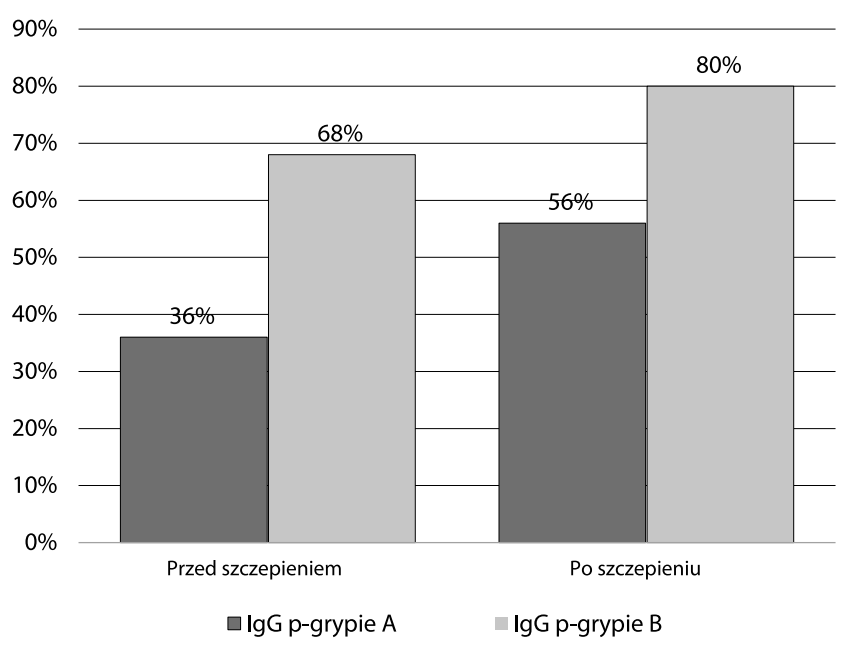

Fig. 2. Percentage of patients with positive concentrations of IgG antibodies against influenza

Ryc. 2. Odsetki pacjentów $\mathrm{z}$ dodatnim stężeniem przeciwciał IgG przeciwko grypie 
Tabela I. Wyniki badania przeciwciał IgG i IgM przeciwko grypie A i B w grupie badaniej Table I. Results of IgG and IgM antibodies against influenza A and B in the study group

\begin{tabular}{|c|c|c|c|c|}
\hline \multicolumn{2}{|c|}{ Influenza A } & Before vaccination & $\begin{array}{c}\text { After vaccination } \\
(4-6 \text { weeks })\end{array}$ & After the season \\
\hline \multirow{2}{*}{ IgG } & $(+)$ & $9 / 25(36 \%)$ & $14 / 25(56 \%)$ & $10 / 17(58,8 \%)$ \\
\cline { 2 - 5 } & $(-)$ & $16 / 25(64 \%)$ & $11 / 25(44 \%)$ & $7 / 17(41,2 \%)$ \\
\hline \multirow{2}{*}{ IgM } & $(+)$ & $6 / 25(24 \%)$ & $15 / 25(60 \%)$ & $3 / 17(17,6 \%)$ \\
\cline { 2 - 5 } & $(-)$ & $19 / 25(76 \%)$ & $10 / 25(40 \%)$ & $14 / 17(82,4 \%)$ \\
\hline \multirow{2}{*}{ Influenza B } & Before vaccination & $\begin{array}{c}\text { After vaccination } \\
(4-6 \text { weeks })\end{array}$ & After the season \\
\hline \multirow{2}{*}{ IgG } & $(+)$ & $17 / 25(68 \%)$ & $20 / 25(80 \%)$ & $13 / 17(76,5 \%)$ \\
\cline { 2 - 5 } & $(-)$ & $8 / 25(32 \%)$ & $5 / 25(20 \%)$ & $4 / 17(23,5 \%)$ \\
\hline \multirow{2}{*}{$\operatorname{IgM}$} & $(+)$ & $5 / 25(20 \%)$ & $13 / 25(52 \%)$ & $3 / 17(17,6 \%)$ \\
\cline { 2 - 5 } & $(-)$ & $20 / 25(80 \%)$ & $12 / 25(48 \%)$ & $14 / 17(82,4 \%)$ \\
\hline
\end{tabular}

There were no adverse post-vaccination reactions observed; moreover, none of patients had a significant decrease in CD4 lymphocytes compared with prevaccination level. HIV viral load was undetectable in most patients both before and after vaccination. Two patients (teenage girl and teenage boy) had the viral load as high as several thousand of copies per milliliter before and after vaccination, but this was presumably related to the lack of adherence to medical instructions regarding pharmacotherapy (both patients had normal CD4 counts).

Eleven patients $(45.8 \%)$ had protective titers of antibodies against $\mathrm{H} 1$ haemagglutinin [i.e. the titer $\geq 1: 40$ ] before vaccination, while the percentage of patients with protective titer 4-6 weeks after vaccination was $52.4 \%$.

\section{DISCUSSION}

The influenza vaccination is a cost-effective preventive method to decrease the morbidity and mortality related to this infectious disease. Due to the high antigenic variability of the influenza virus, the World Health Organization determines the composition of the vaccine each year based on recent research and virology reports (14). According to the National Institute of Hygiene, the main influenza monitoring centre in Poland, in the 2016/2017 epidemic season as many as $99 \%$ of cases were caused by the influenza $\mathrm{A}$ virus and only $1 \%$ by the $\mathrm{B}$ variant. In Lower Silesia (Wroclaw belongs to this voivodeship), the peak incidence of influenza this season was at the turn of January and February 2017 (2). Influenza A (H3N2) infections predominated in Europe at that time, accounting for $76 \%$ of confirmed cases. The efficacy of the vaccine against influenza A (H3N2) in the 2016-2017 season was moderate (38\%) and even lower for subjects older than 65 years (23.4\%) (15).
U 17 pacjentów oznaczono obecność przeciwciał IgG po sezonie grypowym, u 6/17 (35,3\%) i u 3/17 $(17,6 \%)$ - odpowiednio przeciwko grypie A i B - nie stwierdzono dodatniego miana przeciwciał w żadnym z oznaczeń. U 4 osób z wykazanym RNA wirusa grypy A nie stwierdzono serokonwersji przeciwciał IgG.

Po szczepieniu nie obserwowano niepożądanych odczynów poszczepiennych (NOP); ponadto u żadnego z pacjentów nie wykazano istotnego spadku limfocytów CD4 w stosunku do wartości przed szczepieniem. Wiremia HIV u większości pacjentów była niewykrywalna zarówno przed, jak i po szczepieniu. U 2 pacjentów (nastoletnia dziewczynka i nastoletni chłopiec) stwierdzono wiremię HIV rzędu kilka tysięcy kopii/ $\mathrm{ml}$ przed i po szczepieniu, jednak miało to najprawdopodobniej związek z brakiem adherencji i wykazaną w tym czasie opornością na stosowane leczenie (u obojga pacjentów liczba CD4 była prawidłowa).

U 11 pacjentów przed szczepieniem $(45,8 \%)$ wykazano ochronne miano przeciwciał przeciwko hemaglutynie $\mathrm{H} 1$ [tj. miano $\geq 1: 40$ ], z kolei po ok. 4-6 tygodniach od szczepienia odsetek pacjentów z ochronnym mianem wynosił 52,4\%.

\section{DYSKUSJA}

Szczepienie przeciwko grypie jest najskuteczniejszą metodą jej zapobiegania. Z uwagi na dużą zmienność antygenową wirusa grypy Światowa Organizacja Zdrowia ustala przed każdym nadchodzącym sezonem skład szczepionki obowiązującej w danym sezonie epidemicznym (14). Według danych Państwowego Zakładu Higieny, głównego ośrodka monitorującego ds. grypy w Polsce, w sezonie epidemicznym 2016/2017 aż 99\% zachorowań było spowodowanych wirusem grypy typu A i tylko $1 \%$ wirusem typu B. Na Dolnym Śląsku szczyt zapadalności na grypę w tym sezonie przypadł na przełom stycznia i lutego 2017 
In our study group of HIV-infected patients (before vaccination), the positive $\mathrm{IgG}$ antibodies against influenza $\mathrm{A}$ and $\mathrm{B}$ were demonstrated in a significant percentage of patients $-36 \%$ and $68 \%$, respectively. This may be due to previous vaccinations or containment with the virus. After vaccination, a positive concentrations of $\operatorname{IgG}$ antibodies against influenza A and B were found in $56 \%$ and $80 \%$ of patients, respectively. There was also an increase in the number of patients with positive concentration of IgM antibodies after vaccination (see Table I). The given results indicate efficient serological response in our study group, which is consistent with the observations of other authors - protection against viruses that are antigenically similar to those contained in the vaccine may persist for several months (14). The observed increase in the concentration of IgM is a desired and natural phenomenon after vaccination. In our study, the IgM antibodies were assessed relatively shortly after vaccination, hence there is a relatively high percentage of patients with positive IgM. Moreover, as the study conducted among the population of German children showed, the level of IgG antibodies against influenza $\mathrm{A}$ and $\mathrm{B}$ increased gradually with the age of the child (16). In almost $100 \%$ of children aged $>9$ years there were present $\operatorname{IgG}$ antibodies against influenza $\mathrm{A}$, whereas antibodies against influenza $\mathrm{B}$ were found in approx. $80 \%$ children over the age of 13 (16). Hence, special attention should be paid to the immunization of younger children.

According to the European guidelines on the vaccinations in paediatric HIV-infected patients, the subject's immune status constitutes the key factor in the implementation of the vaccination schedule $(12,13)$. It has been shown that the post-vaccination response in HIV-infected patients is depended on the previous immune deficiency, current CD4 count, and the HIV viral load (17). In our study we haven't observed any significant decrease in CD4, nor there was an increase in HIV viral load after the immunization (as mentioned before, in 2 patients there was persistent HIV viral load caused by non-compliance and consequent drug resistance). Analogous results were demonstrated by Marczyńska et al. The authors tested antihemagglutinin antibodies for three strains of influenza virus, and the protective titer against influenza AH1N1, AH3N2 and B before vaccination was shown in $0 \%$, $23.1 \%$ and $0 \%$ of HIV-infected children, respectively. After vaccination, seroprotection was found in 7.7\% (AH1N1), 61.5\% (AH3N2) and 23\% (B). Except for the results for AH1N1, no differences were found between the study and the control group (18). In our patients, a significant percentage of patients $(45.8 \%)$ had a protective titer of antibodies against AH1N1 before vaccination, and more than half of the patients (52.4\%)
(2). W Europie dominowały zakażenia wirusem grypy A (H3N2), stanowiąc $76 \%$ potwierdzonych przypadków. Skuteczności szczepionki przeciw grypie wywołanej przez A (H3N2) w sezonie 2016-2017 była umiarkowana (38\%) i niższa dla osób powyżej 65 lat $(23,4 \%)(15)$.

W naszej badanej grupie pacjentów zakażonych HIV (przed szczepieniem) wykazywano obecność przeciwciał IgG przeciwko grypie A i B u znacznego odsetka pacjentów - odpowiednio 36 i $68 \%$. Może to wynikać z faktu szczepienia tej grupy pacjentów w poprzednich sezonach lub przechorowania grypy w przeszłości. Po szczepieniu dodatnie stężenie przeciwciał IgG stwierdzono u $56 \%$ i $80 \%$ pacjentów - odpowiednio przeciwko grypie A i B. Obserwowano również zwiększenie liczby pacjentów z dodatnim stężeniem przeciwciał IgM po szczepieniu (vide tabela I). Podane wyniki wskazują na zadowalającą odpowiedź serologiczną w badanej grupie pacjentów, jest to również zgodne z obserwacjami innych autorów, że ochrona przed wirusami podobnymi antygenowo do tych, które są zawarte w szczepionce, może utrzymywać się przez okres kilku-kilkunastu miesięcy (14). Ponadto, jak pokazało badanie przeprowadzone wśród populacji dzieci niemieckich, poziom przeciwciał IgG przeciwko grypie A i B zwiększał się stopniowo wraz z wiekiem dziecka - prawie u $100 \%$ badanych powyżej 9 roku życia występowały przeciwciała IgG przeciwko grypie A, z kolei u ok. $80 \%$ dzieci w wieku powyżej 13 roku życia oznaczono przeciwciała tej klasy przeciwko grypie B (16). Dlatego zwraca się szczególną uwagę na konieczność uodpornienia dzieci w młodszym wieku.

Według europejskich wytycznych dotyczących szczepień u pacjentów pediatrycznych zakażonych HIV, kluczowe znaczenie w realizacji ogólnego schematu szczepień ma stan immunologiczny pacjenta $(12,13)$. Wykazano, że wpływ na odpowiedź poszczepienną u zakażonych HIV ma m.in. niedobór odporności w przeszłości, aktualna liczba CD4 czy poziom wiremii HIV (17). W naszej pracy nie wykazano istotnego spadku CD4 i wzrostu wiremii HIV u zakażonych pacjentów po szczepieniu (jak wspomniano, u 2 pacjentów stwierdzono wzrost wiremii HIV spowodowany opornością na leki). Podobne wyniki w swoim badaniu $\mathrm{w}$ grupie dzieci zakażonych HIV uzyskała Marczyńska i wsp. Autorzy cytowanej pracy badali przeciwciała antyhemaglutyninowe dla trzech szczepów wirusa grypy, ochronne miano przed szczepieniem wykazano u $0 \%, 23,1 \%$ i $0 \%$ odpowiednio przeciwko AH1N1, AH3N2, B. Po szczepieniu seroprotekcję stwierdzono u 7,7\% (AH1N1), 61,5\% (AH3N2), 23\% (B). Za wyjątkiem wyników dla AH1N1, nie wykazano różnic między grupą badaną a kontrolną (18). W naszej grupie pacjentów już przed 
after the vaccination. Similar results in the group of HIV-infected children were also published in the paper of Kosalaraksa et al. - protective titers of antibodies against AH1N1 were detected in $42.5 \%$ of subjects before the vaccination (for the remaining strains: AH3N2 - 37.8\%; B - 5.5\%), whereas 30 days after the immunization, the seroprotection was demonstrated in $89 \%$ (AH1N1), 85\% (AH3N2), 48\% (B) of subjects (19).

The evaluation of anti-hemagglutinin antibodies in a haemagglutination inhibition test is the most common method to assess the immunogenicity of influenza vaccination. In our study, we relied on the determination of specific IgG against influenza A and $\mathrm{B}$ by ELISA testing. Many studies have confirmed the correlation of both of the above-mentioned methods $(20,21)$. Simultaneously, the difficulties related to the performance of haemagglutination inhibition tests should be emphasized (high specificity for virus strains, time-consuming, poor availability), which translates into their low usefulness in everyday clinical practice and therefore performing ELISA tests seems to be a reasonable alternative $(16,22)$.

Influenza carries a high risk of bacterial complications (including pneumonia), but frequently - especially in children - this condition is clinically indistinguishable from other, mostly mild, viral respiratory infections. The study conducted a few years ago in our department among HIV-infected children showed significantly fewer mild infections of the respiratory system (the so-called "common cold") compared to the control group (healthy children) during the one year follow-up, while no differences in the incidence of pneumonia were found (23). This is due to several factors, including the use of an extended vaccination schedule in HIV-infected children (including annual influenza vaccination), high awareness of their caregivers about the prevention of respiratory tract infections and easy access to medical services in large university hospital (23). In our study none of the patients developed symptomatic influenza or flu-like infection, although 8 patients showed the presence of RNA of influenza A virus in nasopharyngeal swabs. A half $(4 / 8)$ of patients were PCR positive and influenza A IgG positive; the remaining patients tested positive for PCR did not develop a protective antibody titers, but which is most important, none of these 8 subjects developed clinical symptoms of influenza. This demonstrates that influenza vaccination in pediatric $\mathrm{HIV}$-infected patients is effective in preventing symptomatic influenza infection but does not prevent transmission of infection in the population. One may hypothesize that there are factors other than vaccination that szczepieniem u znacznego odsetka pacjentów $(45,8 \%)$ stwierdzono ochronne miano przeciwciał przeciwko AH1N1, po szczepieniu u ponad połowy badanych $(52,4 \%)$. Podobne wyniki w grupie dzieci zakażonych HIV uzyskała Kosalaraksa i wsp. - u 42,5\% badanych przed szczepieniem wykryto ochronne miano przeciwciał przeciwko AH1N1 (dla pozostałych szczepów: AH3N2 - 37,8\%; B - 5,5\%), natomiast 30 dni po szczepieniu seroprotekcję wykazano u 89\% (AH1N1), $85 \%$ (AH3N2), $48 \%$ (B) (19).

Do oceny immunogenności szczepień przeciwko grypie w wielu badaniach wykorzystuje się ocenę przeciwciał antyhemaglutyninowych $\mathrm{w}$ teście hamowania hemaglutynacji; w naszym badaniu oparliśmy się na oznaczeniu swoistych IgG przeciwko grypie A i B metodą ELISA. W wielu badaniach potwierdzono korelację obu wyżej wymienionych metod $(20,21)$. Jednocześnie podkreśla się trudności związane z wykonywaniem testów hamowania hemaglutynacji (wysoka specyficzność względem szczepów wirusa, czasochłonność, słaba dostępność na rynku), co przekłada się na ich małą przydatność w codziennej praktyce klinicznej, dlatego też wykonywanie testów ELISA wydaje się być dobrą alternatywą $(16,22)$.

Grypa niesie za sobą wysokie ryzyko powikłań bakteryjnych (m.in. zapaleń płuc), często jednak zwłaszcza u dzieci - klinicznie nie jest odróżniania od innych, przeważnie łagodnych wirusowych zakażeń układu oddechowego. W badaniu prowadzonym kilka lat temu w naszej klinice wśród dzieci zakażonych HIV wykazano, że podczas rocznej obserwacji w tej grupie pacjentów występowało istotnie mniej łagodnych infekcji układu oddechowego (tzw. „przeziębień") w porównaniu do grupy kontrolnej (zdrowych dzieci), podczas gdy nie stwierdzono różnic w częstości występowania zapaleń płuc (23). Wynika to z kilku czynników, m.in. stosowania u dzieci zakażonych HIV rozszerzonego schematu szczepień (w tym coroczne szczepienie przeciwko grypie), wysokiej świadomości ich opiekunów na temat zapobiegania infekcjom układu oddechowego oraz łatwego dostępu do wizyt lekarskich (23). W przedstawionym w obecnej pracy badaniu żaden z pacjentów nie zachorował objawowo na grypę lub na infekcję grypopodobną, chociaż u 8 pacjentów wykazano obecność RNA wirusa grypy typu A w wymazie z nosogardła. U 50\% (4/8) pacjentów otrzymano pozytywny wynik badania PCR i dodatnie miano przeciwciał IgG przeciwko grypie A; pozostali pacjenci mieli pozytywny wynik badania PCR, ale nie wytworzyli ochronnego miana przeciwciał poszczepiennych, mimo to u nikogo nie wystapiły objawy kliniczne grypy. Pokazuje to, że szczepienia przeciw grypie u pediatrycznych pacjentów zakażonych HIV są skuteczne w zapobieganiu objawowym zakażeniom wirusami grypy, ale nie zapobiegają transmisji zaka- 
contribute to the absence of symptomatic infection, such as the use of antiretroviral drugs.

Our analyses has certain limitations that need to be acknowledged. A relatively small study group is due to the fact that in Poland the group of children diagnosed with HIV infection is generally small. According to the data of the National AIDS Center, by the end of October 2016, 113 children in Poland were treated with combined antiretroviral therapy, hence our study group accounted for approximately $25 \%$ of all patients in Poland (11). The largest group of patients is supervised and taken care by Warsaw center, whereas Wroclaw center is in second place with regard to the number of paediatric HIV-infected patients. However, it's worthy noting that the number of HIV-infected children, similarly to the adult patients, is presumably significantly underestimated in Poland (11).

There is also a lack of control group in this study - a comparison of the vaccination response to influenza in HIV-infected and healthy children would provide additional imporant data in this field. Data on other anti-haemagglutinin antibodies (not only AH1N1) are also required. Finally, an interesting aspect of our study are presented cases of children with the confirmed presence of influenza virus RNA in the nasopharyngeal material but without clinical symptoms of the disease. Further studies are warranted to address the phenomenon of asymptomatic viral carriage in such unique patient population.

\section{CONCLUSIONS}

Influenza vaccination in paediatric HIV-infected patients is effective in preventing symptomatic influenza virus infection but does not prevent the transmission of infection in the population. Annual influenza vaccinations and seasonal natural infections with influenza viruses result in the persistence of measurable antibody levels until the next epidemic season. For these reasons, such vaccinations should be continued every year, especially in the context of new threats for these patients, such as the current Covid-19 pandemic.

\section{REFERENCES}

1. Centers for Disease Control and Prevention (CDC): Estimated Influenza Illnesses, Medical visits, Hospitalizations, and Deaths in the United States - 2018-2019 influenza season. Available at: https://www.cdc.gov/flu/about/burden/2018-2019. html (accessed 7th Nov 2020)

2. Państwowy Zakład Higieny - Narodowy Instytut Zdrowia Publicznego. Grypa w Polsce http:// wwwold.pzh.gov.pl/oldpage/epimeld/grypa/index. htm (accessed 8th Nov 2020) żeń w populacji. Możliwe, że istnieją inne obok szczepień czynniki wpływające na brak objawów choroby, np. stosowanie leków antyretrowirusowych.

Ograniczeniem prezentowanego badania może się wydawać m.in. niezbyt liczna grupa badana - wynika to jednak z faktu, że w Polsce grupa dzieci zakażonych HIV jest nieliczna. Zgodnie $z$ danymi Krajowego Centrum ds. AIDS, do końca października 2016 roku w Polsce 113 dzieci było objętych leczeniem antyretrowirusowym, dlatego nasza grupa badana stanowiła ok. $25 \%$ wszystkich pacjentów (11). Najliczniejszą grupę pacjentów obejmuje opieką ośrodek warszawski, pod względem liczności pacjentów ośrodek wrocławski znajduje się na drugim miejscu. Należy jednak pamiętać, że liczba dzieci zakażonych HIV, tak jak pacjentów dorosłych, jest w Polsce znacząco niedoszacowana (11).

W powyższym badaniu zwraca również uwagę brak grupy kontrolnej - porównanie stopnia odpowiedzi poszczepiennej przeciwko grypie u dzieci zakażonych HIV i zdrowych stanowiłoby cenne uzupełnienie istniejących danych. Konieczne jest również uzyskanie danych na temat innych przeciwciał antyhemaglutyninowych (nie tylko w kierunku AH1N1). Ciekawym zagadnieniem poruszonym $\mathrm{w}$ naszym badaniu jest zestawienie odpowiedzi poszczepiennej przeciwko grypie i badań wirusologicznych (wykrywanie RNA wirusa grypy) - brak objawowych zakażeń pomimo stwierdzonej obecności RNA wirusa grypy w materiale $\mathrm{z}$ nosogardła - co jest kolejnym argumentem przemawiającym za skutecznością szczepienia przeciwko grypie i koniecznością jego wykonywania.

\section{WNIOSKI}

Szczepienia przeciw grypie u pediatrycznych pacjentów zakażonych HIV są skuteczne w zapobieganiu objawowym zakażeniom wirusami grypy, ale nie zapobiegają transmisji zakażeń w populacji. Coroczne szczepienia przeciwko grypie i sezonowe zakażenia naturalne wirusami grypy skutkują utrzymywaniem się oznaczalnych stężeń przeciwciał do następnego sezonu epidemicznego. $Z$ tych względów należy kontynuować takie szczepienia rokrocznie, a zwłaszcza w obliczu nowych zagrożeń, takich jak obecnie COVID-19.

3. Radwan HM, Cheeseman SH, Lai KK, et al. Influenza in human immunodeficiency virusinfected patients during the 1997-1998 influenza season. Clin Infect Dis. 2000 Aug;31(2):604-6. doi: $10.1086 / 313985$.

4. Lin JC, Nichol KL. Excess mortality due to pneumonia or influenza during influenza seasons among persons with acquired immunodeficiency syndrome. Arch Intern Med. 2001 Feb 12;161(3):441-6. doi: 10.1001/archinte.161.3.441. 
5. Zanetti AR, Amendola A, Besana S, et al. Safety and immunogenicity of influenza vaccination in individuals infected with HIV. Vaccine. 2002 Dec 20;20 Suppl 5:B29-32. doi: 10.1016/s0264410x(02)00511-x.

6. Heikkinen T, Silvennoinen H, Peltola V, et al. Burden of influenza in children in the community. J Infect Dis. 2004 Oct 15;190(8):1369-73. doi: 10.1086/424527. Epub 2004 Sep 15.

7. Neuzil KM, Zhu Y, Griffin M, et al. Burden of interpandemic influenza in children younger than 5 years: a 25 -year prospective study. J Infect Dis. 2002 Jan 15;185(2):147-52. doi: 10.1086/338363. Epub 2001 Dec 17.

8. Africa S, Cohen AL, Hellferscee $\mathrm{O}$, et al. Epidemiology of Influenza Virus Types and Subtypes. 2015;20(7):2009-12.

9. Tempia S, Walaza S, Viboud C, et al. Mortality associated with seasonal and pandemic influenza and respiratory syncytial virus among children $<5$ years of age in a high HIV prevalence setting-South Africa, 1998-2009. Clin Infect Dis 2014 May;58(9):1241-9. doi: 10.1093/cid/ciu095. Epub 2014 Feb 23.

10. Program Szczepień Ochronnych na rok 2021 http://dziennikmz.mz.gov.pl/DUM_MZ/2020/90/ akt.pdf (dostęp: 02.12.2020)

11. Program Polityki Zdrowotnej Ministerstwa Zdrowia pt. „Leczenie antyretrowirusowe osób żyjącychzwirusem HIV w Polscena lata 2017-2021" - 2016 (aktualizacja listopad 2019) PROGRAM ARV_2017-2021_po_aktualizacji_listopad_2019_ Minister_Zdrowia_z_upoważnienia.pdf (dostęp: 02.12 .2020 )

12. Menson E.N., Melando M.J., Castelli G. Guidance on vaccination of $\mathrm{HIV}$-infected children in Europe. HIV Medicine, 2012; 13: 333-336.

13. Rubin LG, Levin MJ, Ljungman P, et al. IDSA clinical practice guideline for vaccination of the immunocompromised host. Clin Infect Dis 2014 Feb;58(3):309-18. doi: 10.1093/cid/cit816. Erratum in: Clin Infect Dis 2014 Jul 1;59(1):144.

14. Grohskopf LA, Alyanak E, Broder KR, et al. Prevention and Control of Seasonal Influenza with Vaccines: Recommendations of the Advisory Committee on Immunization Practices - United States, 2019-20 Influenza Season. MMWR Recomm Rep. 2019 Aug 23;68(3):1-21. doi: 10.15585/mmwr.rr6803al.

15. European Centre for Disease Prevention and Control (ECDC): Summary of the influenza 20162017 season in Europe. Available at: https://www. ecdc.europa.eu/en/publications-data/summaryinfluenza-2016-2017-season-europe (accessed on November 2020).

16. Sauerbrei A, Langenhan T, Brandstadt A, et al. Prevalence of antibodies against influenza
A and B viruses in children in Germany, 2008 to 2010. Euro Surveill. 2014 Feb 6;19(5):20687. doi: 10.2807/1560-7917.es2014.19.5.20687.

17. Yamanaka H, Teruya K, Tanaka M, et al. Efficacy and immunologic responses to influenza vaccine in HIV-1-infected patients. J Acquir Immune Defic Syndr. 2005 Jun 1;39(2):167-73.

18. Marczyńska M, Brydak LB, Machala M, et al. Influenza vaccination in HIV-infected children. Acta Paediatr. 2001 Apr;90(4):466-7.

19. Kosalaraksa P, Srirompotong U, Newman RW, et al. Serological response to trivalent inactive influenza vaccine in HIV-infected children with different immunologic status. Vaccine. 2011 Apr 5;29(16):3055-60. doi: 10.1016/j. vaccine.2011.01.091. Epub 2011 Feb 22.

20. Lau YF, Tang LH, Chien Lye D, et al. Serological response to trivalent inactivated influenza vaccine in HIV-infected adults in Singapore. Hum Vaccin Immunother. 2017 Mar 4;13(3):551-560. doi: 10.1080/21645515.2016.1246636. Epub 2017 Feb 17.

21. Rajendran M, Nachbagauer R, Ermler ME, et al. Analysis of Anti-Influenza Virus Neuraminidase Antibodies in Children, Adults, and the Elderly by ELISA and Enzyme Inhibition: Evidence for Original Antigenic Sin. mBio. 2017 Mar 21;8(2):e02281-16. doi: 10.1128/mBio.02281-16.

22. Tse M, Kim M, Chan $\mathrm{CH}$, et al. Evaluation of three commercially available influenza A typespecific blocking enzyme-linked immunosorbent assays for seroepidemiological studies of influenza A virus infection in pigs. Clin Vaccine Immunol. 2012 Mar;19(3):334-7. doi: 10.1128/CVI.05358-11. Epub 2012 Jan 4.

23. Kuchar E, Dawiec M, Kraszewska-Glomba B, et al. The Incidence of Respiratory Tract Infections in Vertically HIV-Infected Children in Lower Silesia in Poland and the Approach to Infection Prevention. Adv Exp Med Biol. 2015;857:61-6. doi: 10.1007/5584_2015_119.

Received: 13.01.2021 r.

Accepted for publication: 26.02.2021

Otrzymano: 13.01.2021 r.

Zaakceptowano do publikacji: 26.02.2021 r.

\section{Address for correspondence: \\ Adres do korespondencji:}

lek. Katarzyna Tkaczyszyn

Department of Pediatric Infectious Diseases, Wrocław

Medical University

Chałubińskiego 2-2a Str., 50-368 Wrocław

Tel. (71) 7703151

e-mail: katarzyna.tkaczyszyn@gmail.com 